\title{
O DIREITO À DIFERENÇA E A PROTEÇÃO JURÍDICA DAS MINORAIS NA AMÉRICA LATINA
}

\section{André Leonardo Copetti Santos}

Pós-Doutor pela Universidade do Vale do Rio dos Sinos (Unisinos). Possui Mestrado (1999) e Doutorado (2004) em Direito pela Universidade do Vale do Rio dos Sinos e Graduação em Direito pela Universidade de Cruz Alta (1988). Atualmente é professor do corpo permanente do Programa de Pós-Graduação em Direito da Unijuí, Ijuí, RS e do Programa de Pós-Graduação em Direito da URI, Santo Ângelo, RS. Coordenador Executivo do PPGD/Urisan. Editor da Revista Científica Direitos Culturais. Membro fundador da Casa Warat Buenos Aires e da Editora Casa Warat. Advogado criminalista. andre.leonardo@unijui.edu.br

\section{Doglas Cesar Lucas}

Pós-doutor em Direito pela Università degli Studi Roma Tre, Itália. Doutor em Direito pela Unisinos e mestre em Direito pela UFSC. Professor nos cursos de Graduação e de Mestrado em Direito da Unijuí. Professor no curso de Graduação em Direito do Instituto Cenecista de Ensino Superior de Santo Ângelo - lesa. Professor visitante do mestrado em direito da URI - Santo Ângelo. Avaliador MEC/Inep. Consultor ad hoc da Capes. Líder do Grupo de Pesquisa no CNPq Fundamentos e concretização dos Direitos Humanos. doglas।@unijui.edu.br

\section{Resumo}

0 presente texto objetiva apresentar a teorização da diferença e sua importância na construção de novas narrativas e institucionalidades nos campos do direito e da política. 0 trabalho denuncia as precariedades e homogeneizações propagadas pela ideia e pela institucionalização de igualdade abstrata, demonstrando o recente e amplo processo de proteção jurídica da diferença na América Latina. A diferença é enaltecida como condição de possibilidade para a alteridade e para o reconhecimento e visibilidade das minorias que foram excluídas da proteção jurídica pelos processos majoritários que construíram a sua pertença negando a diferença do outro. A diferença insere-se definitivamente no Direito e na política e requer seu estatuto próprio de proteção.

\section{Palavras-chave}

Diferença. Reconhecimento. Minorias. Direitos humanos. 


\section{The Right to Difference and The Legal Protection of Minorities in Latin America}

\section{Abstract}

This paper aims to present the theory of difference and its importance in building new narratives and institutionalities on the fields of law and politics. The work denounces the precariousness and homogenization propagated by the idea and by the institutionalization of the abstract equality, showing the recent and wide legal protection process of the difference in America-Latin. The difference is enhanced as a condition of possibility for the otherness and the recognition and visibility of minorities that were excluded from legal protection by the majority processes that built their belonging by denying the difference of the other. The difference inserts itself definitely on law and policy and requires its own protection status.

\section{Keywords}

Difference. Recognition. Minorities. Human rights.

\section{Sumário}

1 Esboçando o plano de trabalho. 2 Algumas razões teóricas sobre a institucionalização da diferença. 3 A institucionalização legislativa da diferença. 3.1. No espaço internacional. 3.2 No âmbito nacional. 3.2.1 A institucionalização constitucional da tutela da diferença $e$ da hipossuficiência social na América Latina. 3.2.2 A institucionalização da diferença na Constituição Brasileira de 1988. 3.2.3 A institucionalização infraconstitucional da tutela da diferença e da hipossuficiência social no Brasil. $4 \mathrm{~A}$ institucionalização da diferença pelo poder Executivo: as políticas públicas no Brasil. 5 A institucionalização judicial da diferença no Brasil. 6 Considerações finais: sobre a necessidade de se promover diálogos entre as diferenças. 7 Referências. 


\section{ESBOÇANDO O PLANO DE TRABALHO}

A ideia central que aqui propomos fundamenta-se na hipótese de que a salvaguarda política e jurídica dos interesses de grupos minoritários e socialmente vulneráveis, em razão de seus modos de ser diversos dos prescritos pelos sistemas de dominação institucionalizados, não pode ser eficazmente funcionalizada a partir de categorias ou institutos que embasaram razões práticas próprias à proteção de maiorias, mas, num sentido diverso, reclama uma redefinição funcional do Direito, que tome como móvel gerador a consolidação categorial da diferença e não uma busca impossível por uma igualdade que se tem mostrado ao longo da História como uma grande ficção.

Uma das angústias deixadas pelas leituras de Nietzsche e de Warat diz respeito à igualdade, considerada um dos elementos funcionalizadores centrais da política e do Direito modernos. Deslocando a análise da igualdade para o universo de problemas relativos aos grupos sociais minoritários e vulneráveis socialmente nos dias atuais, percebemos inicialmente que essa unidade funcional da Modernidade não é adequada para a abordagem e o tratamento hermenêutico dos direitos, cuja tutela demande o reconhecimento da diferença em sua multiplicidade caleidoscópica, a que podemos nominar como diversidade. Ou seja, no plano instrumental, no estágio civilizatório em que nos encontramos, a adoção de soluçôes diferenciadas que aparentemente impliquem discriminação, para a tutela de direitos cuja concretização fundamenta-se no reconhecimento da diversidade, não somente deve ser tolerada, mas, mais do que isso, estimulada e normativamente institucionalizada, tanto no plano constitucional quanto no infraconstitucional. Dessa forma, o deslocamento categorial em direção à diferença e à diversidade surge como fundamental para as novas demandas sociais contemporâneas.

Essa proposta assenta-se na constatação de que uma das características mais marcantes da época que alguns autores chamam de "a era dos extremos" (Hobsbawm, 1994) ou de a "era da migraçâo" (Castells; Haas; Miller, 2013), é a diversidade étnica e cultural das populações de alguns países, havendo investigadores que chegam a falar em "superdiversidade" (Vertovec, 2007). Nessa mesma direção, é um fato marcante da contemporaneidade, como bem observa Harvey (2012, que muitos Estados do mundo atual caracterizam-se por terem populações multiétnicas, constituídas 
lenta ou rapidamente). $\mathrm{O}$ fato é que o incremento da variedade e da diversidade na composição étnica e cultural de populaçôes de diferentes países no mundo todo é um fenômeno que se agudizou nos dias atuais em virtude da aceleração dos fluxos causados pelo desenvolvimento tecnológico, especialmente se considerarmos as últimas três ou quatro décadas. Processos de integração e desintegração cultural, utilizando as palavras de Featherstone, que caracterizam o pós-modernismo ao mesmo tempo como um símbolo e uma poderosa imagem cultural do desvio da conceitualização da cultural global, menos em termos dos alegados processos de homogeneização e mais em termos de diversidade, de variedade e da riqueza dos discursos populares e locais, dos códigos e das práticas que resistem e produzem a sistematização e a ordem (1999, p. 8).

Essa configuração pluriétnica e pluricultural de muitos países e cidades foi tomada, por exemplo, por Vertovec para introduzir o termo "superdiversity", a fim de destacar as mudanças às quais se assistiu recentemente na Inglaterra, especialmente na cidade de Londres. A noção de superdiversidade emprega-se para sintetizar uma série de traços que afetam o modo de viver das pessoas.

Ainda que o termo de Vertovec seja utilizado mais especificamente para descrever e analisar um fenômeno por ele associado aos processos de mobilidade humana, abrangendo não só aspectos ligados à origem ou à etnicidade, mas também outros vinculados à condição legal diferencial dos imigrantes (e os direitos associados a cada condição), mais do que se centrar na ideia de diversidade, em alusão estrita à etnicidade e à procedência de um país determinado, destaca esse autor a existência de múltiplos elementos que produzem esta superdiversidade, concomitantemente à interação de muitos destes eixos de diferenciação (2007, p. 1.027, 1.028).

Partindo dessa percepção de Vertovec, parece ser quase inquestionável o acontecimento de um incremento violentíssimo de diferenças nas sociedades contemporâneas, não só ligadas à origem nacional das pessoas ou a sua etnicidade, mas múltiplos outros fatores têm atuado como elementos propulsores dessa diversidade, tais como o gênero, a sexualidade, as hipossuficiências socioeconômicas, etc. $\mathrm{O}$ problema da diferença não é uma questão própria dos últimos 30 ou 40 anos. A diferença e sua inclusão em distintas ordens discursivas sempre existiram, ainda que em boa parte da História da humanidade suas mazelas tenham sido invisibilizadas. $\mathrm{O}$ que há, nas últimas décadas, em termos de novidade em relação a isso, é o processo 
de exponencialização da sua visibilidade, o caráter libertador que as narrativas sobre a diferença assumiram e, também, um incipiente processo de institucionalização legislativa, executiva e judicial da tutela da diferença.

O presente trabalho, assim, parte dessa compreensão tresdobrada da diferença: como elemento principal de acontecimentos sociais, de teorias e de institucionalizaçôes. Quanto ao primeiro aspecto - diferença como acontecimento social -, partindo de uma noção política de dominação, temos pensado a diferença desde uma análise que incide essencialmente sobre as relaçóes de poder, entendendo essas reaçóes e respostas como acontecimentos concretos baseados numa razão prática de liberação de ferrolhos repressivos impostos por culturas/narrativas/formaçóes discursivas hegemônicas invisibilizadoras de singularidades.

Sob a segunda perspectiva - a teorização da diferença - temos recorrido às análises sociológicas, filosóficas e epistemológicas para tentar demonstrar o processo de problematizaçáo acadêmica da igualdade, mediante o que poderíamos chamar um turn point das teorias da Modernidade, que se constituiu por meio de uma teoria crítica da igualdade e, concomitantemente, pela construção de uma nova "tradição", ou de novas "tradiçôes" de teorização a partir de uma sintaxe da diferença. É preciso, neste aspecto, destacar que no campo teórico, a partir das movimentaçôes sociais próprias dos anos 60 do século 20, uma gama enorme de teorizaçôes foram elaboradas, como o materialismo cultural, o pós-colonialismo, o hibridismo pós-estruturalista, os estudos subalternos, os diferentes matizes do feminismo, o ginocriticismo, as teorias queer, o criticismo negro, o criticismo negro feminista, etc.

A última relação à qual procuramos conectar a diferença, e sobre a qual dedicamos esta investigaçáo, diz respeito a sua condição de razão prática política e jurídica. Sobre esses dois planos de institucionalização concebemos a diferença e a sua projeção em espaços decisórios/normativos garantidores de práticas de liberdade identitária individuais e coletivas, de culturas, de etnias, de grupos comportamentais e de grupos hipossuficientes submetidos socialmente, que se encontram imobilizados, fixos, bloqueados e cristalizados em estados de dominação.

Nossa decisão investigativa, para o desenvolvimento da pesquisa que ora passamos a descrever, dirige seu foco sobre a terceira perspectiva - as institucionalizaçóes -, em suas variaçóes legislativa, executiva e judicial. 


\section{ALGUMAS RAZÕES TEÓRICAS SOBRE A INSTITUCIONALIZAÇÃO DA DIFERENÇA}

Após destacar apenas indicativamente nossas preocupaçóes acerca da diferença como acontecimento social e como teorização de contraposiçáo às grandes narrativas modernas, entramos no campo investigativo próprio deste trabalho, qual seja, a institucionalizaçáo legislativa, executiva e judicial da diferença na América Latina. Dirigimos nossa atençáo às consequências prático-racionais da diferença, com uma sintaxe capaz de operar a gênese de uma nova realidade empírica nos discursos ético-normativos como o Direito e a política. Em outras palavras, o Direito e a política deslocaram sensivelmente seus focos de tutela de bens sociais fundados na universalidade para bens sociais estruturados sobre uma sintaxe da diferença. Isso alterou de modo bastante significativo não apenas o sentido da política, da democracia e do Direito, mas, fundamentalmente, de suas próprias funcionalidades.

Em primeiro lugar, a concepção de democracia dominante ao longo dos mais de dois séculos de Modernidade passou a sofrer uma série de questionamentos, especialmente a partir de uma alteração de percepção social desencadeada pelo acontecimento das lutas sociais das minorias realizadas a partir da década de 60 do século 20. Durante a maior parte da Modernidade, a ideia e a funcionalidade da democracia estiveram arraigadas à concepção de regra da maioria e às concepçóes de igualdade e de universalidade. As minorias, os diferentes ou os vulneráveis sociais que desejassem participar da vida democrática de algum país ocidental, cujo modelo de participação política fosse de democracia liberal, deveriam, num processo assimilacionista, adaptar-se aceitando as regras de um suposto esquema formal de neutralidade, de igualdade e de universalidade. As democracias liberais sempre tiveram a pretensão de impor às minorias que delas participavam um esquema de conformidade a uma cultura hegemônica.

Assim, a democracia nas "nações cívicas liberais", utilizando uma nomenclatura de Kymlicka (1989; 1996), implicou, durante muito tempo, um divórcio entre o Estado e opçóes materiais que fugissem do padrão comportamental e étnico dominante. Em outras palavras, supostamente os Estados ditos "cívicos liberais" eram neutros em relação à língua, à História, à literatura, ao calendário, etc. Com 
isso tentou-se justificar a adoçáo de um modelo democrático neutro, em que a igualdade viria a ser o elemento fundante de justificação e no qual todos teriam, em tese, as mesmas possibilidades.

Isso, entretanto, constitui-se numa enorme falácia. Mesmo os países "cívicos liberais" adotaram uma postura parcializada em relação a inúmeros aspectos materiais da vida de seus cidadâos. A começar pela Inglaterra, que em seu processo de colonização sempre buscou a propagação da língua e da cultura anglo-saxônica. Da mesma forma a França e a Espanha. O que dizer, por exemplo, do que aconteceu nas Américas, senão que praticamente exterminaram-se todas as culturas locais para dar espaço à cultura das metrópoles?

Contemporaneamente, porém, o que se observa é a existência de sociedades cada vez mais multinacionais, com configuraçóes crescentemente caleidoscópicas e fragmentadas, nas quais grupos minoritários, sob os mais diversos aspectos, convivem ao lado de núcleos étnicos, culturais e socioeconômicos dominantes. Culturas locais estranguladas voltam cada vez mais a respirar; grupos étnicos imigrantes buscam cada vez mais a manutenção de sua pertença cultural, mesmo habitando Estados com uma cultura dominante; grupos comportamentais diversos das maiorias consolidam suas posiçóes políticas, suas opçóes, seus hábitos, suas pulsóes libidinais, mesmo diante de imensas dificuldades impostas por grupos hegemônicos.

Com a ciência de tal realidade sociológica e antropologicamente demonstrada, temos de considerar que, se a concepçáo liberal de democracia ainda possui uma série de elementos conceituais e funcionais ativos em nossas sociedades contemporâneas, especialmente em relação aos direitos de participação política e à necessidade de proteção de uma enorme gama de direitos individuais; por outro lado, há um leque bastante significativo de outros elementos que merece um novo posicionamento ou uma ampliação funcional-institucional, seja do Estado, seja da própria sociedade, notadamente por força das novas demandas colocadas em cena a partir de lutas pela diferença.

Não estamos aqui a afirmar que o princípio da diferença esteja em franca oposição aos princípios que embasam a democracia liberal. Em muitos aspectos, ele até mesmo busca aprofundar algumas visóes de mundo liberais, particularmente quando evocamos a ideia totalmente liberal de tolerância. Os autores que priorizam 
a ideia de diferença, indistintamente - e talvez este seja um forte ponto de agregação dessa nova vertente de pensamento e pesquisa -, entendem que toda comunidade de diferentes tem o direito fundamental a existir e exprimir-se livremente. A questấo essencial, segundo eles, à qual deve ater-se a Filosofia política moderna, é a da tolerância para com as diferenças sociais e culturais. Assim, há nessa perspectiva uma permanência da tolerância em seu viés liberal, no sentido de garantir aos indivíduos o seu direito à liberdade, mas também um alargamento dessa noção significando a possibilidade de construção da dignidade pelo reconhecimento da situação concreta dos indivíduos no mundo, com suas crenças, valores e identidade social e cultural.

O modelo clássico da cidadania liberal não conseguiu institucionalizar mecanismos de proteção da dignidade das culturas, dos comportamentos minoritários diferentes, dos grupos étnicos sufocados por processos de dominação. Esse standard institucional-funcional cívico, apoiado na também clássica dicotomia público/privado, ao exigir a participação dos indivíduos no espaço político (público), dota-os de direitos e deveres idênticos. A fim de não reproduzir as desigualdades da vida privada, os cidadãos devem aprender a viver em condições de igualdade estrita, cada um mostrando-se neutro em suas relações com os outros. Há, assim, no modelo clássico de cidadania, como resquício da formação dos Estados nacionais em torno de uma nação cultural, uma tendência de uniformização, voltada a evitar qualquer espécie de particularidade ligada a uma pertença social, filosófica, religiosa, étnica, linguística ou comportamental. A partir desse padrão civilizatório homogeneizador, Filosofias orientais são bastante questionadas como tal pelas Filosofias ocidentais; novas religiôes, como as new evangélicas, são largamente contestadas por religiôes tradicionais, especialmente pela Igreja Católica; povos e etnias de países colonizados e explorados por naçóes altamente desenvolvidas e predadoras são hoje rechaçados/ segregados nos territórios dos colonizadores; minorias culturais estão vendo suas línguas serem tragadas por idiomas de povos dominadores, como ingleses e espanhóis; minorias comportamentais sofrem profundas discriminaçóes sociais e profissionais, como os homossexuais, ou, então, de forma mais violenta, são punidos criminalmente como os consumidores de substâncias psicoativas consideradas ilícitas hoje.

Ora, tudo isso representa a mais contundente manifestação de uma visão de mundo, de um paradigma homogeneizador, que, nos dias atuais, contraria qualquer perspectiva democrática em seu sentido substancial. A democracia do 
século 21 é uma construção política permanente que deve potencializar as mais diversas possibilidades de reivindicações políticas em favor do pluralismo cultural e comportamental.

Não podemos mais falar em fidelidade prioritária à nação, como pretendem as nações étnicas antiliberais, ou em amassamento étnico dentro de democracias liberais "neutras". Haveremos, neste novo século, de falar em naçôes multiétnicas, em proteger as pequenas naçóes que vivem em sociedades multinacionais, em resgatar direitos de nações avassaladas nos processos históricos de dominação realizados por povos que, em determinados momentos, souberam garantir uma hegemonia militar internacional. A democracia, na perspectiva da sintaxe da diferença, está assentada numa ideia de "diferencialismo igualitário", no qual o reconhecimento das diversidades é posto a serviço da proteção igual de todas as comunidades.

Claude Lefort (1987), em sua clássica obra A Invenção Democrática. Os limites da dominação totalitária, deixou uma importantíssima contribuição à teoria da democracia, com certeza uma das mais consistentes, ao afirmar que o Estado de Direito sempre implicou a possibilidade de uma oposição ao poder, fundada sobre o Direito - oposição ilustrada pelas admoestaçôes ao rei ou pela recusa em submeter-se ao imposto em situaçôes injustificáveis, até mesmo pelo recurso à insurgência contra um governo ilegítimo. A essa noção acrescentou o elemento democrático, afirmando que o Estado democrático excede os limites tradicionalmente atribuídos ao Estado de Direito, pois experimenta direitos que ainda não lhe estâo incorporados; é o teatro de uma contestação cujo objeto não se reduz à conservaçáo de um pacto tacitamente estabelecido, mas se forma a partir de focos que o poder não pode dominar. Assim, para Lefort, desenvolveu-se, sobre a base dos direitos do homem, toda uma história que transgredia as fronteiras nas quais o Estado pretendia se definir, uma história que continua aberta (1987, p. 56). Em outras palavras, democracia, no campo delimitado pelos direitos humanos, é o processo ininterrupto, contínuo, nunca acabado, de enfrentar o instituído e criar socialmente novos direitos, novas experiências políticas a partir da dinâmica de contrapoderes sociais capazes de enfrentar a onipotência do Estado e das administrações burocráticas. 
Esse processo de permanente reconstrução - ou reinstitucionalização democrática modulou sensivelmente a funcionalidade (legislativa, executiva e judicial) dos poderes públicos nas repúblicas que adotaram modelos constitucionais de Estados Democráticos de Direito, reestruturando as possibilidades de relaçóes, tanto no plano internacional entre os Estados soberanos quanto no plano interno nacional entre Estado e sociedade e, também, dentro da própria sociedade.

\section{A INSTITUCIONALIZAÇÃO LEGISLATIVA DA DIFERENÇA}

\subsection{No Espaço Internacional}

No âmbito internacional, o principal espaço de institucionalização da diferença se dá na extensão legislativa das Cartas de Direitos. Presenciamos nos últimos 60 anos a criação de inúmeros documentos de caráter constitucional internacional (Piovesan, 2012) voltados à proteção de direitos cujo cerne valorativo é a diferença, com sentidos históricos totalmente distintos das declaraçóes de direitos oitocentistas, nas quais a igualdade formal era a nota tônica.

$\mathrm{Na}$ estrutura normativa de institucionalização de um sistema global de proteção internacional dos direitos humanos, observamos inúmeros documentos cujo acento axiológico é posto na diferença. Nesse sentido, podemos arrolar os seguintes:

- O Tribunal Penal Internacional e a Convenção Para a Prevenção e Repressão do Crime de Genocídio (1948);

- Convenção Internacional sobre a Eliminação de Todas as Formas de Discriminação Racial (1965);

- Convenção Internacional sobre a Eliminação de Todas as Formas de Discriminação Contra a Mulher (1979);

- Convenção Sobre os Direitos da Criança (1989);

- Convenção Internacional Sobre a Proteção dos Direitos de Todos os Trabalhadores Migrantes e Membros de suas Famílias (1990);

- Convenção Sobre os Direitos das Pessoas com Deficiência (2006). 
Um comentário especial guardamos para a Declaração Universal sobre a Diversidade Cultural, resultado da Conferência Geral da Unesco de 2001, realizada em Paris, que é hoje o grande documento da humanidade a fundamentar todas as Constituiçôes, os textos legais infraconstitucionais e as decisóes judiciais do mundo todo que abrigam conteúdos reconhecedores das identidades das mais diversas minorias. Para Edgar Montiel,

Este é o primeiro acordo político de envergadura universal que busca enquadrar de modo construtivo os efeitos da mundialização no âmbito da cultura. Trata-se de um primeiro esforço para moderar a lógica uniformizante que subjaz nos processos econômicos e tecnológicos mundiais. Permanece nas mãos dos governos, da sociedade civil e da comunidade internacional a decisão de se servir deste instrumento jurídico para criar em seus países e no mundo um clima estável de confiança, de cooperaçáo e de desenvolvimento (2003, p. 17-18).

Esse texto, adotado unanimemente pelos 181 Estados-membros da Unesco, é estruturado mediante princípios e normas de alcance jurídico e eleva, em seu artigo $1^{\circ}$, a diversidade cultural à categoria de Patrimônio Comum da Humanidade. Antes dessa Declaração, outros instrumentos internacionais já haviam sido promulgados pela Unesco, com a finalidade de proteção cultural, entre os quais figuram:

- o Acordo de Florença de 1950;

- o Protocolo de Nairóbi de 1976;

- a Convenção Universal Sobre Direitos de Autor de 1952;

- a Declaração dos Princípios de Cooperação Cultural Internacional de 1966;

- a Convençáa sobre as Medidas que Devem Adotar-se Para Proibir e Impedir a Importação, a Exportação e a Transferência de Propriedades Ilícitas de Bens Culturais de 1970;

- a Convenção Para a Proteção do Patrimônio Mundial Cultural e Natural de 1972;

- a Declaraçáo da Unesco Sobre a Raça e os Prejuízos Raciais de 1978;

- a Recomendação Relativa à Condição do Artista de 1980;

- a Recomendação Sobre a Salvaguarda da Cultura Tradicional e Popular de 1989. 
Esse processo histórico de construção gradual de instituições de proteção internacional dos direitos culturais alcançou o seu paroxismo, no âmbito jurídico, com a Declaração de Paris de 2001, pois esta estabeleceu uma estreita vinculação da diversidade cultural à ideia de direitos humanos. Em seu artigo $4^{\circ}$, dispóe que a defesa da diversidade cultural é um imperativo ético, inseparável da dignidade da pessoa humana. Já no dispositivo seguinte, declara que os direitos culturais são parte integrante dos direitos humanos, que são universais, indissociáveis e interdependentes. Esse artigo, de certa forma, consagra a tese de Walzer (2003) da igual dignidade à diferença como universalização do direito à particularidade cultural. Por fim, no artigo $6^{\circ}$, propugna por uma diversidade cultural acessível a todos, buscando garantir espaços para que todas as culturas possam expressar-se e dar-se a conhecer.

É importante destacar, por fim, que essa Declaração foca suas atençôes em quatro pontos, a saber: 1) Identidade, diversidade e pluralismo; 2) Diversidade cultural e direitos humanos; 3) Diversidade cultural e criatividade e 4) Diversidade cultural e solidariedade internacional.

\subsection{No Âmbito Nacional}

Nos espaços geopolíticos nacionais, a institucionalização da tutela da diferença e da hipossuficiência pode ser encontrada nos âmbitos de funcionalidade dos distintos poderes públicos (Legislativo, Executivo e Judiciário), por meio das ações que lhes são próprias, ou seja, produção de legislações, execução de políticas públicas e produçáo de decisóes judiciais.

\subsection{A institucionalização constitucional da tutela da diferença e da hipossuficiência social na América Latina}

Em primeiro lugar, mencionemos a institucionalização legislativa constitucional. No espaço normativo constitucional, uma boa representação da materialidade da institucionalização legislativa da tutela da diferença e da hipossuficiência, no âmbito dos Estados nacionais, nos é dada pelo constitucionalismo latino-americano. Nele podemos observar, como em nenhuma outra região do mundo, uma forte 
institucionalização normativa desse tipo de tutela, própria da última metade do século passado, e hoje em movimento de capilarização crescente nos níveis de estratificação normativa infraconstitucional. O conteúdo da tabela a seguir é bastante representativo desse movimento de institucionalização legislativa de proteção da diferença no âmbito constitucional de várias naçóes do continente americano.

\begin{tabular}{|c|c|}
\hline $\begin{array}{l}\text { CONSTITUIÇÓES } \\
\text { NACIONAIS }\end{array}$ & OBJETO DE TUTELA/ARTIGO \\
\hline $\begin{array}{l}\text { México }(1917, \text { com } \\
\text { reformas até } 2002)\end{array}$ & $\begin{array}{l}\text { - Contra escravidáo }\left(2^{\circ}\right) \\
\text { - Índios }\left(4^{\circ}\right) \\
\text { - Cidadania - Capítulo IV (34 a } 38)\end{array}$ \\
\hline $\begin{array}{l}\text { Costa Rica }(1949, \text { com } \\
\text { reformas em 2001) }\end{array}$ & $\begin{array}{l}\text { - Crianças (51,71, menores) } \\
\text { - Mulheres (artigo 71) } \\
\text { - Língua original (76) } \\
\text { - Idosos (51) } \\
\text { - Incapaz (51) }\end{array}$ \\
\hline $\begin{array}{l}\text { Uruguai }(1967, \text { com } \\
\text { reformas até 2004) }\end{array}$ & $\begin{array}{l}\text { - Não discriminação }\left(8^{\circ}\right) \\
\text { - Crianças (42) } \\
\text { - Mulheres - trabalho }(54) \\
\text { - Menores - trabalho }(54)\end{array}$ \\
\hline $\begin{array}{l}\text { Panamá (1972, com } \\
\text { reformas de 1978, } 1983 \\
\text { e 1994) }\end{array}$ & $\begin{array}{l}\text { - Preâmbulo- Democracia e dignidade humana } \\
\text { - Contra discriminação de raça, nascimento, classe social, sexo, reli- } \\
\text { gião e ideias políticas (19) } \\
\text { - Capítulo } 2 \text { - Defesa da família, crianças e idosos (52 a 59) } \\
\text { - Mulher trabalhadora (68) } \\
\text { - Cultura (76) } \\
\text { - Tradiçóes folclóricas ( } 83) \\
\text { - Proteção à língua ( } 84 \text { ) } \\
\text { - Saúde, alimentação, criança e adolescente (106) } \\
\text { - Cidadania (125 a 128) }\end{array}$ \\
\hline Cuba (1976) & $\begin{array}{l}\text { - Língua }\left(2^{\circ}\right) \\
\text { - Religiâo }\left(8^{\circ}\right) \\
\text { - Asilo }(13) \\
\text { - Agricultores }(20) \\
\text { - Cidadania }(28,29,30,32) \\
\text { - Imigraçấo }(34) \\
\text { - Menor }(38,40)\end{array}$ \\
\hline $\begin{array}{l}\text { Chile (1980, com } \\
\text { reformas de 2001) }\end{array}$ & $\begin{array}{l}\text { - Não possui disposição nenhuma que tutele a diferença ou a hipos- } \\
\text { suficiência. }\end{array}$ \\
\hline $\begin{array}{l}\text { Honduras (1982, com } \\
\text { reforma até 2006) }\end{array}$ & $\begin{array}{l}\text { - Mulher }(128,6 ; 128,11) \\
\text { - Indígenas }(346) \\
\text { - Línguas }\left(6^{\circ}\right) \\
\text { - Não discriminação }(60 ; 112) \\
\text { - Portadores de necessidades especiais }(120 ; 169) \\
\text { - Crianças e adolescentes }(67 ; 114 ; 119-126 ; 128, \text { inc. } 6 ; 128,7) \\
\text { - Idosos }(117) \\
\text { - Patrimônio Cultural }(172,173) \\
\text { - Homossexuais }(112,116)\end{array}$ \\
\hline
\end{tabular}




\begin{tabular}{|c|c|}
\hline El Salvador (1983) & $\begin{array}{l}\text { - Pessoa humana }\left(1^{\circ}\right) \\
\text { - Exercício das religiōes }(25) \\
\text { - Asilo }(28) \\
\text { - Família }(32) \\
\text { - Menor }(34,36) \\
\text { - Mulher }(42) \\
\text { - Descapacitados }(70) \\
\text { - Nacionalidade }(91) \\
\text { - Bem-estar da população }(118,119) \\
\text { - Pessoa humana }(146) \\
\text { - Direitos humanos }(194)\end{array}$ \\
\hline $\begin{array}{l}\text { Guatemala }(1985 \text {, com } \\
\text { reformas de } 1993)\end{array}$ & $\begin{array}{ll}\text { - } & \text { Mulher }(18, \mathrm{~B} ; 52 ; 102, \mathrm{~K}) \\
\text { - } & \text { Indígenas }(66-70 ; 76) \\
\text { - } & \text { Línguas de povos originários - bilíngue }(76 ; 143) \\
\text { - } & \text { Não discriminação de trabalhadores }(102, \mathrm{C}) \\
\text { - } & \text { Nấo discriminação, igualdade de direitos homens e mulheres }\left(4^{\circ}\right) \\
\text { - } & \text { Portadores de necessidades especiais }(102, \mathrm{M}) \\
\text { - } & \text { Crianças e adolescentes }(20 ; 50 ; 51 ; 54 ; 102, \mathrm{~L}) \\
\text { - } & \text { Idosos }(51 ; 102, \mathrm{~L} ; 18, \mathrm{C}) \\
\text { - } & \text { Diversidade étnica e cultura }(57-65 ; 71 ; 72 ; 135, \mathrm{C} ; 143)\end{array}$ \\
\hline Haiti (1987) & $\begin{array}{l}\text { - Não discriminação, igualdade (preâmbulo; } 18) \\
\text { - } \\
\text { - } \\
\text { - }\end{array}$ \\
\hline $\begin{array}{l}\text { Nicarágua }(1987, \text { com } \\
\text { reformas de } 1995,2000 \text {, } \\
2005 \text {. }\end{array}$ & $\begin{array}{l}\text { - Contra discriminação }\left(3^{\circ} \text { e } 4^{\circ}\right) \\
\text { - Dignidade da pessoa humana }\left(5^{\circ}\right) \\
\text { - Indios (5) } \\
\text { - Contra discriminação de nascimento, nacionalidade, crença polí- } \\
\text { tica, raça, sexo (27) } \\
\text { - Menores (35) } \\
\text { - Proteção às famílias e vítimas de guerra (56) } \\
\text { - Educação e cultura (58) } \\
\text { - Descapacitados (62) } \\
\text { - Menores (76) } \\
\text { - Idosos (77) } \\
\text { - Proibição de exploração de menores (84) } \\
\text { - Capítulo VI. Direitos das Comunidades da Costa Atlântica - mes- } \\
\text { mos da Nicarágua (89) } \\
\text { - Liberdade de língua e cultura (90) } \\
\text { - Autonomia para os povos indígenas e comunidades étnicas da Cos- } \\
\text { ta Atlântica (181) }\end{array}$ \\
\hline $\begin{array}{l}\text { Colômbia (1991, com } \\
\text { reformas de 2001) }\end{array}$ & $\begin{array}{ll}\text { - } & \text { Pluralismo }\left(1^{\circ}\right) \\
\text { - } & \text { Não discriminação }\left(5^{\circ}\right) \\
\text { - } & \text { Diversidade étnica }\left(7^{\circ}\right) \\
\text { - } & \text { Idiomas originários }(10) \\
\text { - } & \text { Não discriminação }(13) \\
\text { - } & \text { Mulher }(43) \\
\text { - } & \text { Criança e adolescente }(44,45,50) \\
\text { - } & \text { Idosos }(46) \\
\text { - } & \text { Portadores de necessidades especiais }(47)\end{array}$ \\
\hline
\end{tabular}




\begin{tabular}{|c|c|}
\hline Paraguai (1992) & $\begin{array}{l}\text { - } \text { Democracia pluralista (Preâmbulo, } 1^{\circ} \text {, segundo parágrafo) } \\
\text { - Mulher }(48,89) \\
\text { - Criança }(54) \\
\text { - } \\
\text { - } \text { Adolescência }(56) \\
\text { - } \text { Portados }(57) \\
\text { - Índios }(62,63,64,65,66,67) \\
\text { - Língua originária }(77,140)\end{array}$ \\
\hline Peru (1993) & $\begin{array}{ll}\text { - } & \text { Não discriminação }(2 \% / 2) \\
\text { - } & \text { Pluralidade étnica e cultural }(2 \% / 19) \\
\text { - } & \text { Línguas de povos originários }(2 \% / 19 \text {, parág. }) \\
\text { - } & \text { Educação bilíngue e intercultural (17/parág. } 3)\end{array}$ \\
\hline Argentina (1994) & $\begin{array}{l}\text { - } \quad \text { Criança artigo } 75(22,23) \\
\text { - } \quad \text { Mulheres artigo 37; artigo } 75(22,23) \\
\text { - } \text { Idosos artigo } 75(23) \\
\text { - } \\
\text { Descapacitados artigo } 75(23)\end{array}$ \\
\hline Equador 1998 & 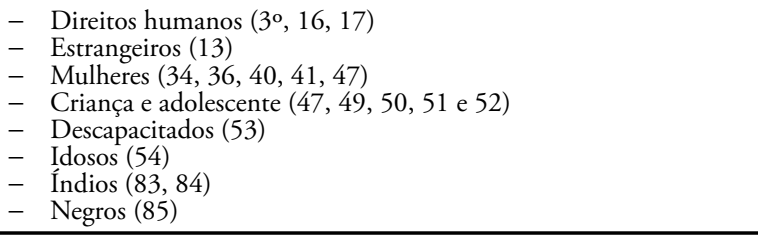 \\
\hline Venezuela (1999) & 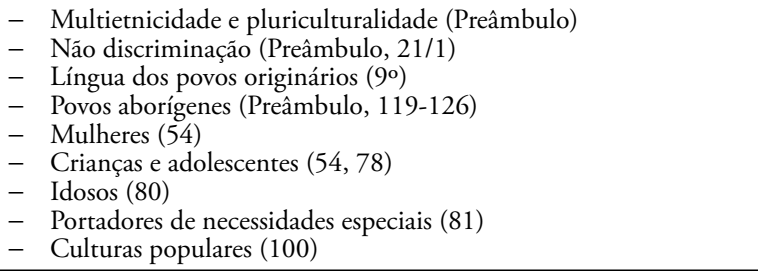 \\
\hline $\begin{array}{l}\text { República Dominicana } \\
\text { (2002) }\end{array}$ & $\begin{array}{l}\text { - Proteçáo a mulheres e crianças }\left(8^{\circ}-15 \text { a, d) }\right. \\
\text { - Cidadania }(12 \text { a } 15) \\
\text { - Cultura }(101)\end{array}$ \\
\hline Bolívia (2008) & 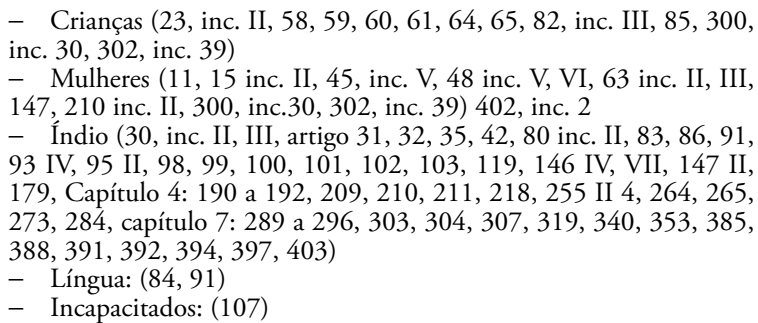 \\
\hline
\end{tabular}

Fonte: Os autores. 


\subsubsection{A institucionalização da diferença na Constituição brasileira de 1988}

Como jamais ocorrera em toda a história do constitucionalismo brasileiro, o texto da Carta Política de 1988 consagrou a tutela da diversidade cultural e de algumas minorias, estruturando-se num nível de diferenciação radicalmente distinto de todos os textos anteriores e criando uma série de novas demandas/possibilidades normativas no patamar regulatório infraconstitucional.

\section{O Preâmbulo}

No Brasil, o sistema jurídico foi pródigo na recepção dos postulados da diferença. Comecemos pelo Preâmbulo da Magna Carta, no qual princípios fundantes da Filosofia política da diferença aparecem manifestamente. Vale repeti-lo: "Nós, representantes do povo brasileiro, reunidos em Assembléia Nacional Constituinte, para instituir um Estado Democrático de Direito, destinado a assegurar o exercício dos direitos sociais e individuais, a liberdade, a segurança, o bem-estar, o desenvolvimento, a igualdade e a justiça como valores supremos de uma sociedade fraterna, pluralista e sem preconceitos...”. Tais termos presentes no texto constitucional revelam, sem qualquer espécie de dúvida, que o projeto político constitucional não admite hegemonias culturais, comportamentais, étnicas, etc. Mais do que isso. Ao constarem tais previsóes no Preâmbulo, surgem elas como cânones hermenêuticos a serem adotados em todo e qualquer movimento jurídico que venha a ser feito dentro do sistema jurídico do país.

\section{Os princípios fundamentais e sua potencialidade de sentido para uma tutela da diferença}

O texto constitucional, no entanto, vai mais longe. Diferentemente de outras Constituiçôes brasileiras que se revestiram de um caráter altamente autoritário, o texto de 1988 contemplou, como fundamentos da República Federativa do Brasil, a cidadania, a dignidade da pessoa humana e o pluralismo político. 
As ideias de cidadania e de dignidade da pessoa humana devem ser lidas e compreendidas dentro da totalidade de um novo projeto de sociedade, Estado e Direito, com a positivaçáo de diferentes núcleos de direitos fundamentais - individuais e coletivos -, como nunca ocorrera anteriormente na vida constitucional do país. Devem ter seu sentido construído a partir de uma significativa ampliação da complexidade axiológica constitucional, em que não mais prevalece uma ideologia liberal ou social, mas fragmentos de todas compóem um quadro democrático caleidoscópico, no qual todos são iguais perante a lei, inclusive em suas diferenças.

A ideia de pluralismo político também vai ao encontro de todo esse arcabouço de multiplicidades abrigado no texto constitucional de 1988. E nem poderia ser diferente. O pluralismo político é uma condição de possibilidade principiológica para que toda e qualquer pretensão política possa se fazer representar dentro do sistema democrático. Não faria sentido haver a projeção de uma sociedade pluralista no Preâmbulo se em alguma outra parte não houvesse uma previsão que instrumentalizasse a possibilidade dessa pluralidade social fazer-se representar no quadro democrático.

Especificando ainda mais o Preâmbulo, o artigo $3^{\circ}$, em seu inciso IV, prevê que constituem objetivos fundamentais da República Federativa do Brasil, entre outros, promover o bem de todos, sem preconceitos de origem, raça, sexo, cor, idade e outras formas de discriminação. Esse dispositivo, somado aos previstos no artigo $5^{\circ}$, incisos XLI e XLII, os quais preveem, respectivamente, que a lei punirá qualquer discriminação atentatória dos direitos e liberdades fundamentais e que a prática do racismo constitui crime inafiançável e imprescritível, sujeito à pena de reclusão, nos termos da lei, consagra definitivamente a recepção pela Constituição brasileira dos postulados filosófico-políticos do multiculturalismo e da política da diferença.

Como se isso não bastasse, a Constituição Federal brasileira inovou radicalmente ao prever outras formas de proteção aos mais diversos grupos minoritários e vulneráveis em nossa sociedade.

\section{A proteção e o estímulo constitucional das manifestações culturais de grupos participantes do processo civilizatório nacional}

No capítulo referente à educação, à cultura e ao desporto, inovou a Constituição de 88 em relação aos textos constitucionais anteriores, ao prever uma seção específica destinada à proteção e ao estímulo à cultura, adotando uma perspectiva 
diferenciadora e multiculturalista. De forma ainda mais vanguardista, avançou no sentido de valorizar a diversidade cultural que caracteriza a formação da identidade brasileira. Nesse sentido, o texto constitucional contém expressas disposições referentes à necessidade de tutela e estímulo à manutenção da diversidade étnica e cultural, tais como:

- a garantia a todos do pleno exercício dos direitos culturais (artigo 215, caput);

- a previsão de proteção das manifestações culturais populares, indígenas, afro-brasileiras e de outros grupos participantes do processo civilizatório nacional (artigo 215, $\$ 1^{\circ}$ );

- a imposição constitucional ao legislador comum para a fixação, mediante lei, de datas comemorativas de alta significação para os diferentes segmentos étnicos nacionais (artigo $215, \$ 2$ );

- o estabelecimento da obrigatoriedade de um Plano Nacional de Cultura, que vise ao desenvolvimento cultural, mediante a realização de açóes do poder público que conduza, dentre outras coisas, à valorização cultural da diversidade étnica e regional (artigo 215, $\$ 3^{\circ}, \mathrm{V}$ ).

\section{A tutela às pessoas deficientes}

Se em outras épocas e em outras Constituições os portadores de deficiência, em suas mais variadas formas, eram relegados ao esquecimento, o mesmo não pode ser dito a partir do advento da Constituição de 1988. A proteção aos deficientes é hoje largamente positivada em nosso texto constitucional. Estabelece a Magna Carta, em seu artigo 23, II, ser competência comum da Uniáo, dos Estados, do Distrito Federal e dos municípios cuidar da saúde e assistência pública, da proteção e garantia das pessoas portadoras de deficiência. No mesmo passo a previsão contida no artigo 24, XIV, segundo a qual compete à União, aos Estados e ao Distrito Federal legislar concorrentemente sobre proteção e integração social das pessoas portadoras de deficiência. 
Especificando um pouco mais o sentido constitucional da tutela aos portadores de deficiência, o texto constitucional consagra consideráveis previsóes regulatórias de inclusão, tais como as seguintes:

- a igualdade de direitos no trabalho (artigo $7^{\circ}, \mathrm{XXXI}$ );

- a reserva de percentual dos cargos e empregos públicos para pessoas portadoras de deficiência (artigo 37, VIII);

- a previsão da habilitação e reabilitação das pessoas portadoras de deficiência e a promoção de sua integração à vida comunitária, bem como a garantia de um salário mínimo de benefício mensal, como objetivos da assistência social (artigo 203, IV e V);

- o atendimento educacional especializado (artigo 208, III);

- a facilitação das condiçóes para um acesso adequado e a necessidade de adaptação dos logradouros, edifícios de uso público e meios de transporte para tal fim (artigo 227, $\$ 2^{\circ}$ ).

\section{A proteção das fases hipossuficientes da cadeia existencial: a criança, 0 adolescente, o jovem e o idoso}

A Constituição de 88 também radicalizou no que pode ser chamado de fases hipossuficientes da cadeia existencial humana, a saber: a infância, a adolescência e a velhice.

A proteção à infância é prevista como direito social já no artigo $6^{\circ} \mathrm{da} \mathrm{CF}$. A relevância para o Estado de tal tutela é tamanha que a Constituição também estabelece como competência concorrente da Uniáo, dos Estados e do Distrito Federal legislar sobre a proteção à infância e à juventude (artigo 24, XV). Assim como em relação aos deficientes, a Constituição também especifica em uma série de dispositivos a proteção à infância e à juventude. Vejamos:

- são objetivos da assistência social a proteção à infância e à adolescência e o amparo às crianças e adolescentes carentes (artigo 203, I e II); 
- é dever da família, da sociedade e do Estado assegurar à criança e ao adolescente, com absoluta prioridade, o direito à vida, à saúde, à alimentação, à educaçáo, ao lazer, à profissionalização, à cultura, à dignidade, ao respeito, à liberdade e à convivência familiar e comunitária, além de colocá-los a salvo de toda forma de negligência, discriminação, exploração, violência, crueldade e opressão (artigo 227, caput);

- a imposição ao Estado da obrigação de promover programas de assistência integral à saúde da criança e da adolescência (artigo 227, \$ $1^{\circ}$ );

- a previsão da proteção especial nos seguintes aspectos: idade mínima de 14 anos para admissão ao trabalho; garantia de direitos previdenciários e trabalhistas; garantia de acesso do trabalhador adolescente à escola; garantia de pleno e formal conhecimento da atribuição de ato infracional, igualdade na relação processual e defesa técnica por profissional habilitado; obediência aos princípios da brevidade, excepcionalidade e respeito à condição peculiar de pessoa em desenvolvimento quando da aplicação de qualquer medida privativa de liberdade; estímulo do poder público, mediante assistência jurídica, incentivos fiscais e subsídios, ao acolhimento sob a forma de guarda, de criança ou adolescente órfão ou abandonado; programas de prevenção e atendimento especializado à criança e ao adolescente dependente de entorpecentes e drogas afins;

- regras específicas relativas à assistência social (artigo 227, \$70).

Assim como crianças e adolescentes, os idosos também gozam, pela sua vulnerabilidade, de especial tutela constitucional. Assim, nesta direção, as seguintes disposiçóes constitucionais:

- a proteção à velhice como objetivo da assistência social (artigo 203, I);

- a garantia de um salário mínimo de benefício mensal à pessoa idosa (artigo 203, V);

- a obrigação dos filhos maiores ajudarem e ampararem os pais na velhice, na carência ou enfermidade (artigo 229);

- a obrigação da família, da sociedade e do Estado de amparar as pessoas idosas, mediante a garantia de sua participação na comunidade, da defesa de sua dignidade e do bem-estar e da garantia do direito à vida (artigo 230, caput); 
- a previsão de programas de amparo (artigo $230, \$ 11^{\circ}$ );

- a garantia da gratuidade dos transportes coletivos urbanos aos maiores de 65 anos (artigo 230, $\$ 2$ ).

Tais medidas protetivas decorrem da adoção constitucional dos princípios da solidariedade e da proteção, o que revela uma atenção diferenciada no projeto constitucional para esses polos vulneráveis da cadeia existencial.

\section{A proteção da identidade indígena}

Tendo a proteção genérica disposta nos princípios gerais da ordem social, os índios tiveram uma consideração especial da Constituição no que toca à proteção de sua identidade. É a positivação, em nível legislativo constitucional, do princípio da proteção da identidade, na qual se destacou maior preocupação do legislador constituinte com a preservaçáo do seu entorno natural e da manutenção de sua relação cultural com esse ambiente, o que, de certa forma, constitui-se em condição de possibilidade da sobrevivência da organização social, costumes, línguas, crenças e tradiçôes indígenas, ou, em outras palavras, da cultura e identidade indígenas.

\subsubsection{A institucionalização infraconstitucional da tutela da diferença e da hipossuficiência social no Brasil}

Boa parte da positivação constitucional voltada à tutela da diferença projetou-se também para as esferas infraconstitucionais do ordenamento jurídico brasileiro, fenômeno que permitiu evidenciar o afastamento do Direito infraconstitucional dos moldes do Direito liberal clássico - caracterizado pela tutela de bens individuais e universalmente válidos -, e a aproximação de um Direito cuja finalidade radica-se na tutela da diferença, tanto sob a forma de minorias quanto de vulneráveis sociais. Tais projeçóes do campo constitucional para a seara infraconstitucional deram-se em especial por força das obrigaçóes das indicaçóes legislativas constitucionais constantes no texto da Carta Magna brasileira de 1988. O resultado disso é que hoje, no Brasil, o Direito infraconstitucional, sensível ao movimento constitucional de mitigação de um projeto liberal homogeneizador, está 
mais próximo de uma concepção contemporânea de democracia, ao recepcionar a ideia de diferença, concretizada nas demandas dos grupos minoritários residentes em nosso país.

Já antes de 1988 havia algumas legislaçóes que davam conta da tutela da diferença e da vulnerabilidade, ainda que poucas, como a Lei no . 6.001/73, que criou o Estatuto do Índio, no qual há um capítulo com a positivação dos crimes contra os indígenas. É depois de 88, porém, que a tutela da diferença e da vulnerabilidade de minorias realmente começa a ser positivada de forma mais efetiva. Alguns exemplos, sem a pretensão de sermos exaustivos, são bastante significativos. A Lei no ${ }^{\circ}$ 7.716/89, que define os crimes de preconceitos de raça e cor; a Lei no. 7.853/89, que dispóe sobre o apoio às pessoas portadoras de deficiência, sua integraçáo social, institui a tutela jurisdicional de interesses coletivos e difusos dessas pessoas, disciplina a atuação do Ministério Público e define crimes; a Lei no. 8.069/90, que dispóe sobre o Estatuto da Criança e do Adolescente; a Lei no 12.852/2013, que criou o Estatuto da Juventude; a Lei no ${ }^{\circ}$ 9.029/95, que proíbe a exigência de atestados de gravidez e esterilização e outras práticas discriminatórias para efeitos admissionais e/ou de permanência da relação jurídica de trabalho; a Lei no. 9.455/97, que define os crimes de tortura, prevendo uma causa de aumento de pena em seu artigo $1^{\circ}, \$ 4^{\circ}$, para os casos em que o crime de tortura é praticado contra criança, gestante, portador de deficiência, adolescente ou maior de 60 (sessenta) anos; a Lei no. 10.741/03, que dispóe sobre o Estatuto do Idoso; a Lei no ${ }^{\circ}$ 11.340/06, que cria mecanismos para coibir a violência doméstica contra a mulher e, como último exemplo, talvez o mais significativo de todos, a Lei $\mathrm{n}^{\circ}$. 12.288/2010, que institui o Estatuto da Igualdade Racial, destinado a garantir à população negra a efetivação da igualdade de oportunidades, a defesa dos direitos étnicos individuais, coletivos e difusos e o combate à discriminação e às demais formas de intolerância étnica.

\section{A INSTITUCIONALIZAÇÃO DA DIFERENÇA PELO PODER EXECUTIVO: as Políticas Públicas no Brasil}

$\mathrm{Na}$ esfera de atuação do poder Executivo no Brasil, uma série de políticas públicas, consistentes em conjuntos de programas, açôes e atividades desenvolvidas pelo Estado, direta ou indiretamente, com a participação de entes públicos ou 
privados, visam a assegurar determinados direitos de cidadania, de forma difusa ou para determinado segmento social, cultural, étnico ou econômico. Elas traduzem uma tendência recente de atuação governamental em total consonância com os projetos republicanos e democráticos contemporâneos de efetivação da cidadania. Dez exemplos que se seguem são bastante expressivos dessa redisposição do poder Executivo no Brasil, na execução de políticas públicas voltadas a parcelas específicas da população. A saber:

- a Política Nacional de Saúde da Pessoa Idosa

- o Sistema Nacional de Juventude - Sinajuve

- a Política Nacional de Saúde Integral de Lésbicas, Gays, Bissexuais, Travestis e Transexuais

- a Política Nacional de Saúde Integral da População Negra

- a Política Nacional de Atenção à Saúde dos Povos Indígenas

- a Política Nacional de Desenvolvimento Sustentável dos Povos e Comunidades Tradicionais

- o Plano Nacional de Direitos Humanos

- o Plano Nacional de Pessoas com Deficiência

- o Programa Nacional de Política para Mulheres

- o Programa Nacional Brasil sem Homofobia

- o Programa Nacional de Promoção da Igualdade Racial

$\mathrm{Na}$ maior parte dos casos essas políticas constituem-se de ações articuladas entre vários ministérios e órgãos governamentais, cuja principal finalidade é a formulação de projetos específicos de empoderamento de grupos discriminados, garantindo o acesso e a permanência desses públicos nas mais diversas áreas (educação, saúde, mercado de trabalho, geração de renda, direitos humanos e outros).

Os planos estabelecem diretrizes, prioridades e objetivos gerais a serem alcançados em períodos relativamente longos. Por exemplo, os planos decenais de educação têm o sentido de estabelecer objetivos e metas estratégicas a serem alcançados pelos governos e pela sociedade ao longo de dez anos. Os programas 
estabelecem, por sua vez, objetivos gerais e específicos focados em determinado tema, público, conjunto institucional ou área geográfica. Açóes visam ao alcance de determinado objetivo estabelecido pelo Programa, e a atividade, por sua vez, visa a dar concretude à ação.

\section{A INSTITUCIONALIZAÇÃO JUDICIAL DA DIFERENÇA NO BRASIL}

$\mathrm{Na}$ seara judicial, muitas decisões recentes têm corroborado esse novo momento de institucionalização da diferença, revelando uma aclimatação do Poder Judiciário ao projeto de sociedade, Estado e Direito constitucionalizado. Pelo exercício da função contramajoritária do poder Judiciário, tornou-se possível a proteção das minorias e hipossuficientes, pois esse tipo de tutela qualifica-se como fundamento imprescindível à plena legitimação material do Estado Democrático de Direito. Dessa forma, não resta dúvida de que incumbe ao Supremo Tribunal Federal, principalmente, mas também aos demais Tribunais, em sua condição institucional de guarda da Constituição (o que lhe confere "o monopólio da última palavra” em matéria de interpretação constitucional), desempenhar função contramajoritária, em ordem a dispensar efetiva proteção às minorias contra eventuais excessos (ou omissóes) da maioria, eis que ninguém se sobrepóe, nem mesmo os grupos majoritários, à autoridade hierárquico-normativa e aos princípios superiores consagrados na lei fundamental do Estado.

Nesse sentido, por exemplo, o habeas corpus 82424, julgado em 17/9/2003, que consagrou o princípio da imprescritibilidade do crime de racismo, ao enfrentar essa delicada matéria em processo cujo fato delituoso atribuído ao paciente - crime de racismo - consistiu em escrever, editar, divulgar e comerciar livros "fazendo apologia de ideias preconceituosas e discriminatórias" contra a comunidade judaica (Lei 7716/89, artigo 20, na redação dada pela Lei 8081/90). A ordem nesse caso foi denegada. A ementa é referencial neste tema: ${ }^{1}$

1 Os textos das jurisprudências citadas daqui para a frente estão com a grafia original, havendo, portanto, inúmeras discrepâncias em relaçáo ao Acordo Ortográfico em vigência. Assim deixamos de usar o termo sic para alertar o leitor acerca de todos os casos em que alguns termos que não estáo de acordo com a nova normatização da língua portuguesa. 
HABEAS-CORPUS. PUBLICAÇÃO DE LIVROS: ANTI-SEMITISMO. RACISMO. CRIME IMPRESCRITÍVEL. CONCEITUAÇĀO. ABRANGÊNCIA CONSTITUCIONAL. LIBERDADE DE EXPRESSÃO. LIMITES. ORDEM DENEGADA. 1. Escrever, editar, divulgar e comerciar livros "fazendo apologia de ideias preconceituosas e discriminatórias" contra a comunidade judaica (Lei 7716/89, artigo 20, na redação dada pela Lei 8081/90) constitui crime de racismo sujeito às cláusulas de inafiançabilidade e imprescritibilidade (CF, artigo $5^{\circ}$, XLII).

Também emblemática e portadora de uma substancial Filosofia da alteridade é a decisão na Açáo Popular no. 3.388, distribuída no ano de 2005, que decidiu pela demarcação da Reserva Indígena Raposa Serra do Sol. A decisão dessa ação vem exatamente ao encontro de demandas históricas dos povos originários no sentido da reivindicação de territórios por eles ancestralmente ocupados. Esse julgado consagrou os dispositivos constitucionais constantes nos artigos 231e 232, que determinam a tutela dos direitos originários dos indígenas sobre suas terras.

Houve o reconhecimento da condição indígena da área demarcada, em sua totalidade, com a adoção de um modelo contínuo de demarcação, consolidando-se, assim, um regime constitucional de demarcaçáo das terras indígenas e a Constituição Federal como estatuto jurídico da causa indígena. Os argumentos da decisão são relevantes na medida em que consideram a demarcação das terras indígenas como capítulo avançado do constitucionalismo fraternal e, também, reforçam a importância da demarcação como fator de inclusão comunitária pela via da identidade étnica. Alguns argumentos, expostos nas razôes de decidir, são superlativos na consolidação da institucionalização judicial da diferença, tais como:

1. O SIGNIFICADO DO SUBSTANTIVO “ÍNDIOS” NA CONSTITUIÇÃO FEDERAL. O substantivo “índios” é usado pela Constituição Federal de 1988 por um modo invariavelmente plural, para exprimir a diferenciação dos aborígenes por numerosas etnias. Propósito constitucional de retratar uma diversidade indígena tanto interétnica quanto intra-étnica. Índios em processo de aculturação permanecem índios para o fim de proteção constitucional. Proteção constitucional que não se limita aos silvícolas, estes, sim, índios ainda em primitivo estádio de habitantes da selva. 


\section{AS TERRAS INDÍGENAS COMO PARTE ESSENCIAL DO TERRI-} TÓRIO BRASILEIRO. As “terras indígenas" versadas pela Constituição Federal de 1988 fazem parte de um território estatal-brasileiro sobre o qual incide, com exclusividade, o Direito nacional. E como tudo o mais que faz parte do domínio de qualquer das pessoas federadas brasileiras, são terras que se submetem unicamente ao primeiro dos princípios regentes das relaçóes internacionais da República Federativa do Brasil: a soberania ou "independência nacional" (inciso I do artigo $1^{\circ} \mathrm{da} C F$ ). Todas as «terras indígenas» são um bem público federal (inciso XI do artigo 20 da CF), o que não significa dizer que o ato em si da demarcação extinga ou amesquinhe qualquer unidade federada. Primeiro, porque as unidades federadas pós-Constituição de 1988 já nascem com seu território jungido ao regime constitucional de preexistência dos direitos originários dos índios sobre as terras por eles "tradicionalmente ocupadas". Segundo, porque a titularidade de bens não se confunde com o senhorio de um território político. Nenhuma terra indígena se eleva ao patamar de território político, assim como nenhuma etnia ou comunidade indígena se constitui em unidade federada. Cuida-se, cada etnia indígena, de realidade sócio-cultural, e não de natureza político-territorial.

3. AS TERRAS INDÍGENAS COMO CATEGORIA JURÍDICA DISTINTA DE TERRITÓRIOS INDÍGENAS. O DESABONO CONSTITUCIONAL AOS VOCÁBULOS “POVO”, "PAÍS”, “TERRITÓRIO”, "PÁTRIA" OU "NAÇÃO” INDÍGENA. Somente o "território” enquanto categoria jurídico-política é que se póe como o preciso âmbito espacial de incidência de uma dada Ordem Jurídica soberana, ou autônoma. O substantivo "terras" é termo que assume compostura nitidamente sócio-cultural, e não política. A Constituição teve o cuidado de não falar em territórios indígenas, mas, tão-só, em "terras indígenas”. A traduzir que os "grupos", "organizaçôes", "populaçôes" ou "comunidades" indígenas não constituem pessoa federada. Não formam circunscrição ou instância espacial que se orne de dimensão política. Daí não se reconhecer a qualquer das organizaçóes sociais indígenas, ao conjunto delas, ou à sua base peculiarmente antropológica a dimensão de instância transnacional. Pelo que nenhuma das comunidades indígenas brasileiras detém estatura normativa para comparecer perante a Ordem Jurídica Internacional como "Nação", "País", "Pátria", "território nacional" ou "povo" independente. Sendo de 
fácil percepção que todas as vezes em que a Constituição de 1988 tratou de "nacionalidade" e dos demais vocábulos aspeados (País, Pátria, território nacional e povo) foi para se referir ao Brasil por inteiro.

4. A DEMARCAÇÃO DE TERRAS INDÍGENAS COMO CAPÍTULO AVANÇADO DO CONSTITUCIONALISMO FRATERNAL. Os arts. 231 e 232 da Constituição Federal são de finalidade nitidamente fraternal ou solidária, própria de uma quadra constitucional que se volta para a efetivação de um novo tipo de igualdade: a igualdade civil-moral de minorias, tendo em vista o proto-valor da integração comunitária. Era constitucional compensatória de desvantagens historicamente acumuladas, a se viabilizar por mecanismos oficiais de açóes afirmativas. No caso, os índios a desfrutar de um espaço fundiário que lhes assegure meios dignos de subsistência econômica para mais eficazmente poderem preservar sua identidade somática, linguística e cultural. Processo de uma aculturação que não se dilui no convívio com os não-índios, pois a aculturação de que trata a Constituição não é perda de identidade étnica, mas somatório de mundividências. Uma soma, e não uma subtração. Ganho, e não perda. Relaçôes interétnicas de mútuo proveito, a caracterizar ganhos culturais incessantemente cumulativos. Concretização constitucional do valor da inclusão comunitária pela via da identidade étnica.

5. O FALSO ANTAGONISMO ENTRE A QUESTÃO INDÍGENA E O DESENVOLVIMENTO. Ao Poder Público de todas as dimensões federativas o que incumbe não é subestimar, e muito menos hostilizar comunidades indígenas brasileiras, mas tirar proveito delas para diversificar o potencial econômico-cultural dos seus territórios (dos entes federativos). O desenvolvimento que se fizer sem ou contra os índios, ali onde eles se encontrarem instalados por modo tradicional, à data da Constituição de 1988, desrespeita o objetivo fundamental do inciso II do artigo $3^{\circ}$ da Constituição Federal, assecuratório de um tipo de «desenvolvimento nacional» tão ecologicamente equilibrado quanto humanizado e culturalmente diversificado, de modo a incorporar a realidade indígena.

6. O CONTEÚDO POSITIVO DO ATO DE DEMARCAÇÃO DAS TERRAS INDÍGENAS. (f.1.) O marco temporal de ocupação. A Constituição Federal trabalhou com data certa -- a data da promulgação dela própria (5 de outubro de 1988) -- como insubstituível referencial para o 
dado da ocupação de um determinado espaço geográfico por essa ou aquela etnia aborígene; ou seja, para o reconhecimento, aos índios, dos direitos originários sobre as terras que tradicionalmente ocupam. (f.2). O marco da tradicionalidade da ocupação. É preciso que esse estar coletivamente situado em certo espaço fundiário também ostente o caráter da perdurabilidade, no sentido anímico e psíquico de continuidade etnográfica. A tradicionalidade da posse nativa, no entanto, não se perde onde, ao tempo da promulgação da Lei Maior de 1988, a reocupação apenas não ocorreu por efeito de renitente esbulho por parte de não-índios. Caso das "fazendas" situadas na Terra Indígena Raposa Serra do Sol, cuja ocupação não arrefeceu nos índios sua capacidade de resistência e de afirmação da sua peculiar presença em todo o complexo geográfico da "Raposa Serra do Sol". (f.3) O marco da concreta abrangência fundiária e da finalidade prática da ocupação tradicional. Áreas indígenas são demarcadas para servir concretamente de habitação permanente dos índios de uma determinada etnia, de par com as terras utilizadas para suas atividades produtivas, mais as "imprescindíveis à preservação dos recursos ambientais necessários a seu bem-estar" e ainda aquelas que se revelarem "necessárias à reprodução física e cultural" de cada qual das comunidades étnico-indígenas, "segundo seus usos, costumes e tradições" (usos, costumes e tradiçôes deles, indígenas, e não usos, costumes e tradições dos não-índios). Terra indígena, no imaginário coletivo aborígine, não é um simples objeto de direito, mas ganha a dimensão de verdadeiro ente ou ser que resume em si toda ancestralidade, toda coetaneidade e toda posteridade de uma etnia. Donde a proibição constitucional de se remover os índios das terras por eles tradicionalmente ocupadas, assim como o reconhecimento do direito a uma posse permanente e usufruto exclusivo, de parelha com a regra de que todas essas terras "são inalienáveis e indisponíveis, e os direitos sobre elas, imprescritíveis" ( $\$ 4^{\circ}$ do artigo 231 da Constituição Federal). O que termina por fazer desse tipo tradicional de posse um heterodoxo instituto de Direito Constitucional, e não uma ortodoxa figura de Direito Civil. Donde a clara intelecção de que OS ARTIGOS 231 E 232 DA CONSTITUIÇÃO FEDERAL CONSTITUEM UM COMPLETO ESTATUTO JURÍDICO DA CAUSA INDÍGENA. (f.4.) O marco do conceito fundiariamente extensivo do chamado "princípio da proporcionalidade”. A Constituição de 1988 faz dos usos, costumes e tradiçóes indígenas o engate lógico para a compreensão, entre outras, das semânticas da posse, da permanência, da habitação, da 
produção econômica e da reprodução física e cultural das etnias nativas. $\mathrm{O}$ próprio conceito do chamado "princípio da proporcionalidade", quando aplicado ao tema da demarcação das terras indígenas, ganha um conteúdo peculiarmente extensivo.

7. DIREITOS “ORIGINÁRIOS”. Os direitos dos índios sobre as terras que tradicionalmente ocupam foram constitucionalmente "reconhecidos", e não simplesmente outorgados, com o que o ato de demarcação se orna de natureza declaratória, e não propriamente constitutiva. 13. O MODELO PECULIARMENTE CONTÍNUO DE DEMARCAÇÃO DAS TERRAS INDÍGENAS. O modelo de demarcação das terras indígenas é orientado pela ideia de continuidade. Demarcação por fronteiras vivas ou abertas em seu interior, para que se forme um perfil coletivo e se afirme a auto-suficiência econômica de toda uma comunidade usufrutuária. Modelo bem mais serviente da ideia cultural e econômica de abertura de horizontes do que de fechamento em "bolsôes", "ilhas", "blocos" ou "clusters", a evitar que se dizime o espírito pela eliminação progressiva dos elementos de uma dada cultura (etnocídio).

\section{A DEMARCAÇÃO NECESSARIAMENTE ENDÓGENA OU IN-} TRAÉTNICA. Cada etnia autóctone tem para si, com exclusividade, uma porção de terra compatível com sua peculiar forma de organização social.

Provavelmente, contudo, as açóes dos movimentos sociais que mais tenham sido recepcionadas pelo Direito brasileiro, particularmente pelo poder Judiciário, são decorrentes da marcha histórica concretizada pelos movimentos dos homossexuais. A discrepância entre a experiência social dos homossexuais e suas expectativas sociais gerou, nas últimas décadas, um tensionamento entre a função reguladora e a função emancipatória de um modelo de Direito que tem suas bases ainda fixadas sobre o paradigma da Modernidade. Por meio de seus movimentos sociais, os homossexuais passaram a manifestar publicamente a ideia de que não basta apenas uma sociedade regulada no presente, ou, com outras palavras, de que o Direito deve apenas objetivar uma sociedade em ordem, mas, além disso, o Direito deve garantir uma sociedade boa, em ordem e dirigida ao futuro, na qual seus integrantes, em suas singularidades, possam ser felizes no presente. Boaventura de Sousa Santos bem esclarece essa exigência em relação às funções reguladora e emancipatória do Direito 
contemporâneo, ao afirmar que "mientras que la regulación garantiza el orden en la sociedad tal como existe en un momento y lugar, la emancipación es la aspiración a un orden bueno en una sociedade buena en el futuro (2009, p. 31).

Nesse sentido, as lutas emancipatórias dos homossexuais nas últimas décadas, após séculos de opressão, começaram a colher seus êxitos com a constituição de novas relaçóes políticas entre suas experiências e suas expectativas de boa vida para o futuro, e, consequentemente, uma estabilizaçáo das expectativas a um novo nível civilizatório, mais exigente e inclusivo. Ou seja, os homossexuais tiveram sucesso na medida em que suas lutas emancipatórias tiveram a potencialidade de se transformarem em novas formas de regulação, mediante as quais a ordem boa almejada de forma fluida pelos movimentos se converteu em ordem.

Nesses processos de estabilização das expectativas dos homossexuais pela sua institucionalização jurídica, é importante apontar que o poder Judiciário, juntamente com o Executivo, tem sido, no Brasil, um destacado protagonista dessa institucionalização da diferença, materializando decisóes de vanguarda com alta repercussão coletiva, fazendo com que a ordem institucional coincida com a boa ordem social e, dessa forma, as açôes sociais passem a ter novos significados e orientaçóes emancipatórias. Cremos que o poder Legislativo tem tido uma atuação mais lenta em temas que exigem fortes rupturas paradigmáticas, como as demandas dos homossexuais, em virtude de sua composição ser bem mais conservadora. Veja-se, por exemplo, o peso da bancada religiosa, assumidamente tradicionalista em questôes táo controversas, como a que ora estamos a abordar, nos processos legislativos e nas decisões do Parlamento brasileiro.

O que segue, em termos de decisóes do poder Judiciário brasileiro, abrange um universo temático considerável, que expressa temas importantíssimos nas expectativas de vida boa para os homossexuais. É relevante destacar que o âmbito temático das demandas iniciais evoluiu e, na medida em que foram se estabilizando, criaram condiçóes institucionais que permitiram avanços enormes em outras áreas de interesse, gerando um cenário político-jurídico cada vez mais inclusivo, possibilitando que o imaginário social de estranhamento em relação às demandas dos homossexuais se dissipe cada vez mais. 
Uma sequência de decisóes, pelos tribunais brasileiros, criou um espaço de cidadania, sem precedentes em nossa História, para os indivíduos que amam e desejam pessoas do mesmo sexo. Decisóes que foram inicialmente tomadas em tribunais inferiores culminaram com a decisão prolatada na ADI 4277, decorrente da encampação dos argumentos da ADPF 132, que reinterpretou o artigo 1723 do Código Civil, para reconhecer a uniáo homoafetiva como instituto jurídico, aproximando o mundo artificial das instituiçôes do mundo natural da vida em suas mais eróticas manifestaçôes. A decisão dessa ADI foi estruturada sobre alguns argumentos importantíssimos em termos de institucionalização judicial da diferença, como, por exemplo:

1. PROIBIÇÃO DE DISCRIMINAÇÃO DAS PESSOAS EM RAZÃO DO SEXO, SEJA NO PLANO DA DICOTOMIA HOMEM/MULHER (GÊNERO), SEJA NO PLANO DA ORIENTAÇÃO SEXUAL DE CADA QUAL DELES. A PROIBIÇÁO DO PRECONCEITO COMO CAPÍTULO DO CONSTITUCIONALISMO FRATERNAL. HOMENAGEM AO PLURALISMO COMO VALOR SÓCIO-POLÍTICO-CULTURAL. LIBERDADE PARA DISPOR DA PRÓPRIA SEXUALIDADE, INSERIDA NA CATEGORIA DOS DIREITOS FUNDAMENTAIS DO INDIVIIDUO, EXPRESSÃO QUE É DA AUTONOMIA DE VONTADE. DIREITO À INTIMIDADE E À VIDA PRIVADA. CLÁUSULA PÉTREA. O sexo das pessoas, salvo disposição constitucional expressa ou implícita em sentido contrário, náo se presta como fator de desigualaçáo jurídica. Proibiçáo de preconceito, à luz do inciso IV do artigo $3^{\circ} \mathrm{da}$ Constituição Federal, por colidir frontalmente com o objetivo constitucional de "promover o bem de todos". Silêncio normativo da Carta Magna a respeito do concreto uso do sexo dos indivíduos como saque da kelseniana "norma geral negativa", segundo a qual "o que náo estiver juridicamente proibido, ou obrigado, está juridicamente permitido". Reconhecimento do direito à preferência sexual como direta emanação do princípio da "dignidade da pessoa humana": direito a auto-estima no mais elevado ponto da consciência do indivíduo. Direito à busca da felicidade. Salto normativo da proibiçáo do preconceito para a proclamação do direito à liberdade sexual. O concreto uso da sexualidade faz parte da autonomia 
da vontade das pessoas naturais. Empírico uso da sexualidade nos planos da intimidade e da privacidade constitucionalmente tuteladas. Autonomia da vontade. Cláusula pétrea.

2. TRATAMENTO CONSTITUCIONAL DA INSTITUIÇÃO DA FAMÍLIA. RECONHECIMENTO DE QUE A CONSTITUIÇÃO FEDERAL NÃO EMPRESTA AO SUBSTANTIVO "FAMÍLIA" NENHUM SIGNIFICADO ORTODOXO OU DA PRÓPRIA TÉCNICA JURÍDICA. A FAMÍLIA COMO CATEGORIA SÓCIO-CULTURAL E PRINCÍPIO ESPIRITUAL. DIREITO SUBJETIVO DE CONSTITUIR FAMÍLIA. INTERPRETAÇÃO NÃO-REDUCIONISTA. O caput do artigo 226 confere à família, base da sociedade, especial proteção do Estado. Ênfase constitucional à instituição da família. Família em seu coloquial ou proverbial significado de núcleo doméstico, pouco importando se formal ou informalmente constituída, ou se integrada por casais heteroafetivos ou por pares homoafetivos. A Constituição de 1988, ao utilizar-se da expressão "família", não limita sua formação a casais heteroafetivos nem a formalidade cartorária, celebração civil ou liturgia religiosa. Família como instituição privada que, voluntariamente constituída entre pessoas adultas, mantém com o Estado e a sociedade civil uma necessária relação tricotômica. Núcleo familiar que é o principal lócus institucional de concreção dos direitos fundamentais que a própria Constituição designa por "intimidade e vida privada" (inciso X do artigo $5^{\circ}$ ). Isonomia entre casais heteroafetivos e pares homoafetivos que somente ganha plenitude de sentido se desembocar no igual direito subjetivo à formaçáo de uma autonomizada família. Família como figura central ou continente, de que tudo o mais é conteúdo. Imperiosidade da interpretação não-reducionista do conceito de família como instituição que também se forma por vias distintas do casamento civil. Avanço da Constituição Federal de 1988 no plano dos costumes. Caminhada na direção do pluralismo como categoria sócio-político-cultural. Competência do Supremo Tribunal Federal para manter, interpretativamente, o Texto Magno na posse do seu fundamental atributo da coerência, o que passa pela eliminaçáo de preconceito quanto à orientação sexual das pessoas.

3. UNIÃO ESTÁVEL. NORMAÇÃO CONSTITUCIONAL REFERIDAA HOMEM E MULHER, MAS APENAS PARA ESPECIAL PROTEÇÃO DESTA ÚLTIMA. FOCADO PROPÓSITO CONSTITUCIONAL 
DE ESTABELECER RELAÇÓES JURÍDICAS HORIZONTAIS OU SEM HIERARQUIA ENTRE AS DUAS TIPOLOGIAS DO GÊNERO HUMANO. IDENTIDADE CONSTITUCIONAL DOS CONCEITOS DE “ENTIDADE FAMILIAR” E “FAMÍLIA”. A referência constitucional à dualidade básica homem/mulher, no $\$ 3^{\circ}$ do seu artigo 226, deve-se ao centrado intuito de não se perder a menor oportunidade para favorecer relaçóes jurídicas horizontais ou sem hierarquia no âmbito das sociedades domésticas. Reforço normativo a um mais eficiente combate à renitência patriarcal dos costumes brasileiros. Impossibilidade de uso da letra da Constituição para ressuscitar o artigo 175 da Carta de 1967/1969. Não há como fazer rolar a cabeça do artigo 226 no patíbulo do seu parágrafo terceiro. Dispositivo que, ao utilizar da terminologia "entidade familiar", não pretendeu diferenciá-la da "família". Inexistência de hierarquia ou diferença de qualidade jurídica entre as duas formas de constituição de um novo e autonomizado núcleo doméstico. Emprego do fraseado "entidade familiar” como sinônimo perfeito de família. A Constituição não interdita a formação de família por pessoas do mesmo sexo. Consagração do juízo de que não se proíbe nada a ninguém senão em face de um direito ou de proteção de um legítimo interesse de outrem, ou de toda a sociedade, o que não se dá na hipótese sub judice. Inexistência do direito dos indivíduos heteroafetivos à sua não-equiparação jurídica com os indivíduos homoafetivos. Aplicabilidade do $\$ 2^{\circ}$ do artigo $5^{\circ}$ da Constituição Federal, a evidenciar que outros direitos e garantias, não expressamente listados na Constituição, emergem "do regime e dos princípios por ela adotados", verbis: "Os direitos e garantias expressos nesta Constituição não excluem outros decorrentes do regime e dos princípios por ela adotados, ou dos tratados internacionais em que a República Federativa do Brasil seja parte”.

4. INTERPRETAÇÃO DO ARTIGO 1.723 DO CÓDIGO CIVIL EM CONFORMIDADE COM A CONSTITUIÇÃO FEDERAL (TÉCNICA DA “INTERPRETAÇÃO CONFORME"). RECONHECIMENTO DA UNIÃO HOMOAFETIVA COMO FAMÍLIA. PROCEDÊNCIA DAS AÇÓES. Ante a possibilidade de interpretação em sentido preconceituoso ou discriminatório do artigo 1.723 do Código Civil, não resolúvel à luz dele próprio, faz-se necessária a utilização da técnica de "interpretação conforme à Constituição". Isso para excluir do dispositivo em causa qualquer significado que impeça o reconhecimento da uniâo contínua, pública 
e duradoura entre pessoas do mesmo sexo como família. Reconhecimento que é de ser feito segundo as mesmas regras e com as mesmas consequências da união estável heteroafetiva.

Essa decisão veio na esteira de outras decisōes referentes a casais homoafetivos que se referiam a outros tipos de demandas, tais como: a adoçáo de menores por casais homossexuais (Recurso Especial No 889.852 - RS 2006, Ap. Cível. No 1.0470.08.047254-6/001/MG, Ap. Cível 582499-9/PR), o reconhecimento das uniốes homoafetivas como sociedades de fato para fins de partilha de bens (Resp. 648.763/RS), o reconhecimento do direito à pensão por morte de um dos membros da uniâo homoafetiva em razão da morte do titular do plano de previdência (Resp. 1.026.981/RJ, 238.715RS), a geração do direito a um dos membros da uniáo homoafetiva de ser incluso no plano de saúde do companheiro (Resp. 238.715RS), reconhecimento do direito à herança (Apelação Cível n. 000730938.2003.8.19.0204/RJ), reconhecimento do direito a verbas rescisórias do de cujus a serem divididas igualitariamente entre sua filha e seu companheiro (Ap. Cível n. 0003873-96.2002.8.19.0207/ RJ).

Tais decisôes revelam a importância da institucionalização, pelo poder Judiciário, de soluçóes para as demandas expressas por esses novos movimentos sociais e marcadas, em sua essência, por uma Filosofia da alteridade. Apenas a ocorrência dos movimentos não teria garantido a estabilização das demandas de tais movimentos.

\section{CONSIDERAÇÕES FINAIS:}

\section{sobre a necessidade de se promover diálogos entre as diferenças}

Estar cada vez mais interconectado com o mundo e ter consciência disso não significa que a humanidade se encontra reunida em uma única aldeia. Diferenças muito grandes existem no interior das naçóes e na relaçáo entre elas, de modo que a identidade não se constitui facilmente, mesmo que mais aproximadas estejam as pessoas e as culturas, senão que esse processo, muitas vezes, até acirra suas marcas distintivas. Um indivíduo que se abre para o mundo tende a se deparar com o estranho e com o diferente de forma bem mais intensa do que se acostumou na cercania nacionalista. Esse contato com o outro será bem mais republicano e demo- 
crático se produzir entendimentos e diálogos que se baseiam mais na prevalência do homem enquanto tal do que nas identidades que escondem o homem por detrás do cidadão nacional (francês, alemão, brasileiro), da religião, da raça, da cor, do gênero, etc. Uma aproximação dessa ordem é indispensável para a superação da imagem do outro como estrangeiro, como estranho, eis que uma sociedade fundada no reconhecimento recíproco dos direitos humanos não é limitada pela ideia de pátria, raça, religião, sexo, idade, etc., mas inaugura uma perspectiva de diálogo em que nada é tido como estranho, em que as múltiplas cidadanias não insistam em seus próprios direitos de modo incondicional (Baratta, 2000).

As identidades não podem ser vistas como atributos ou características do inimigo. A diferença do outro não pode ser uma diferença carregada de exclusão. É saber que não existe igualdade sem diferenças, mas a diferença, como manifestação da humanidade comum, não é, por si só, causa ou motivação para nenhum tipo de arbítrio. As estratégias normativas de se reconhecer a identidade não podem acabar, rivalizar ou vulnerabilizar com as diferenças, mas devem conduzir um processo de responsabilização recíproca, capaz de atender aos reclamos do Direito enquanto mecanismo de proteção da máxima liberdade das diferenças publicamente confrontadas e ajustadas. Como bem referiu Eligio Resta, não se pode transformar a identidade numa obsessão, pois da mesma forma que a identidade une ela também separa; inclui excluindo; une separando; produz continuidade pela negação da intervenção das diferenças. Por isso, as diferenças e as igualdades não podem ser objeto de uma normatização exclusivamente impositiva, resultado de uma ação vinda de fora. É necessário um Direito, como denominou Resta, fraterno, um direito jurado por todos, que destitua o jogo amigo-inimigo, que seja inclusivo, que comprometa e responsabilize a todos e que olhe para "all'umanità come um 'luogo comune' e nom come l'astrazione che confonde tutto e maschera le diferenze" (2008, p. 132).

É preciso resistir aos encantos de uma posição essencialmente culturalista e tradicional de "eu" identitário que, invariavelmente, alimenta novos e velhos comunitarismos e reforça a própria dicotomia que se pretende combater, qual seja: os de dentro e os de fora; nós e eles; estrangeiros e nacionais, etc. É verdade que somos diferentes, que temos histórias de vida distintas, que nascemos em lugares variados, que o gênero e a nacionalidade nos separam, que, enfim, somos dotados de individualidade e historicidade. Não é menos verdadeiro, no entanto, 
que partilhamos uma humanidade comum que permite e dá sentido às diferenças que demandamos. Razão, identidade, culto, sexualidade, desejos, por exemplo, são experiências humanas que podem variar de cultura para cultura, mas não têm sua existência enquanto tal condicionada à realidade histórica objetiva; são temas lotados de humanidade compartilhada. O que se quer dizer é que o homem é igual e diferente, que precisa, portanto, proteger igualdades e diferenças. Isso requer, obviamente, uma negociaçáo mais complexa que uma proposta historicista de alteridade; sugere uma aproximação dialogal entre homem histórico e concepção universal de humanidade. Mais que isso, a identidade, como forma a ser demandada e reivindicada, exige mediaçôes entre a compreensão histórica de sua constituição enquanto realidade objetiva e a aceitação moral das diferenças que podem ser toleradas pela dimensão comum de humanidade. Se isso não for possível ou desejável, a identidade comportará todo tipo de diferenças legítimas (independentemente de seus conteúdos) e toda a ideia de direitos humanos e de alteridade será esvaziada.

Inegavelmente as diferenças vieram à fala, ganharam visibilidade e proteção jurídica e política. O desafio agora é estimular diálogos que impeçam os guetos identitários e a geraçáo de discursos excludentes. Estratégias que apostam na diferença a qualquer preço tenderão a isolar e distanciar as próprias diferenças, aumentando os níveis de afirmação de si em contraposição às diferenças que vêm de fora. Não existe projeto democrático maduro que não reconheça, proteja e estimule o diálogo entre as diferenças de todo tipo, reduzindo os níveis de segregação social e ampliando a intensidade de sua igualdade.

\section{REFERÊNCIAS}

BARATTA, Alessandro. El Estado-mestizo y la ciudadanía plural. Consideraciones sobre una teoría mundana de la alianza. In: GORSKI, Héctor C. Silveira (Org.). Identidades comunitárias y democracia. Madrid: Trotta, 2000.

CASTLES, Stephen; HAAS, Hein de; MILLER, Mark J. The Age of Migration: International Population Movements in the Modern World. 15. ed. New York: The Guilford Press, 2013.

FEATHERSTONE, Mike. Cultura global: introdução. In: FEATHERSTONE, Mike (Coord.). Cultura global. Nacionalismo. Globalização e modernidade. 3. ed. Petrópolis: Vozes, 1999.

HARVEY, David. Sociologia. 6. ed. Porto Alegre: Penso, 2012. 
HOBSBAWM, Eric. Nations and Nationalism since 1870. 2. ed. Cambridge: Cambridge University Press, 2013.

HOBSBAWM, Eric. The Age of Extremes. London: Michael Joseph, 1994.

KYMLICKA, Will. Ciudadanía multicultural. Una teoría liberal de los derechos de las minorias. Traducción Carme Castells Auleda. Barcelona: Paidós, 1996.

. La política vernácula. Nacionalismo, multiculturalismo y ciudadanía. Traducción Tomás Fernandéz Aúz y Beatriz Eguibar. Barcelona: Paidós, 2003.

. Liberalism, community, and culture. Oxford: Oxford University Press, 1989.

LEFORT, Claude. A invenção democrática. Os limites da dominação totalitária. 2. ed. São Paulo: Brasiliense, 1987.

MONTIEL, Edgar. A nova ordem simbólica: a diversidade cultural na era da globalização. In: SIDEKUM, Antônio (Org.). Alteridade e multiculturalismo. Ijuí: Ed. Unijuí, 2003.

NIETZSCHE, Friedrich. Ecce Homo. Trad. Marcelo Backes. Porto Alegre: LPM, 2003.

. Além do bem e do mal. Prelúdio de uma filosofia do futuro. Trad. Mário Ferreira dos Santos. Petrópolis: Vozes, 2009.

. Genealogia da Moral. Trad. Paulo César de Souza. São Paulo: Brasiliense, 1987.

PIOVESAN, Flávia. Direitos Humanos e o Direito Constitucional Internacional. 13. ed., rev. e atual. São Paulo: Saraiva, 2012.

RESTA, Eligio. Diritto Fraterno. Roma-Bari: Laterza, 2008.

SANTOS, Boaventura de Sousa. Sociología jurídica critica. Para un nuevo sentido común en el derecho. Madrid: Trotta, 2009.

VERTOVEC, Steven. "Superdiversity' and its implications". In: Ethnic and racial studies. v. 30, n. 6, p. 1.024-1.054, 2007.

. Multiculturalisms. In: MARTINIELLO, M. (Ed.). Multicultural Policies and the State: a comparision of Two European Societies. Utrecht: Utrecht University, 1998. p. 25-38.

WALZER, Michael. Comentário ao ensaio de Taylor. In: TAYLOR, Charles et al. Multiculturalismo - examinando a política de reconhecimento. Lisboa: Piaget, 1998.

. Esferas de justiça. Uma defesa do pluralismo e da igualdade. Tradução Jussara Simóes. São Paulo: Martins Fontes, 2003.

WARAT, Luis Alberto. A ciência jurídica e seus dois maridos. 2. ed. Santa Cruz: Edunisc, 2000.

. Introdução geral ao Direito. O Direito não estudado pela teoria jurídica moderna.

V. III. Porto Alegre: Safe, 1997.

Recebido em: 26/10/2015

Aceito em: 26/10/2015 